\title{
REGIONAL OUTCROPS WITH DIDACTIC INTEREST AND SEDIMENTARY FACIES ASSOCIATION OF THE ITARARÉ Group AT SÃo PAUlo (BRAZIL)
}

\author{
Sérgio Bergamaschi ${ }^{1 *}$, Ana Carolina de Faria Duarte ${ }^{2}$, Júlia Salles Serrano ${ }^{2}$, Arthur de Mello Bertrand \\ Figueiredo $^{2}$, Lucas Cazelli Vasconcelos ${ }^{2}$, Renata Marins Alvim Gama de Oliveira ${ }^{1}$, Marcus Viní́cius Berao \\ AdE $^{1}$, ANdré Eduardo Piacentini Pinheiro ${ }^{3}$ and Maria Virgínia Alves Martins ${ }^{1,4}$
}

1 Universidade do Estado do Rio de Janeiro, Faculdade de Geologia, Departamento de Estratigrafia e Paleontologia. Rua São Francisco Xavier, 524, sala 2020A, Maracanã, 20550-013, Rio de Janeiro, RJ, Brazil.sergioberg7@hotmail.com, renata.oliveira@uerj.br, marcus.ade@uerj.br, virginia.martins@ua.pt

2 Undergraduate students of Universidade do Estado do Rio de Janeiro, Faculdade de Geologia. Rua São Francisco Xavier, 524, Maracanã, 20550-013, Rio de Janeiro, RJ, Brazil. ana.cfduarte@hotmail.com, jujusserrano@gmail.com, arthur94mbf@hotmail.com, lucaslogia@gmail.com

3 Departamento de Ciências (DCIEN), Faculdade de Formação de Professores (FFP), Universidade do Estado do Rio de Janeiro (UERJ), Rua Francisco Portela, 1470, Patronato, 24435-005, São Gonçalo, RJ, Brazil.paleolones@yahoo.com.br

4 Universidade de Aveiro, Departamento de Geociências, GeoBioTec, 3810-193 Aveiro, Portugal.

* Corresponding AUTHOR, sergioberg7@hotmail.com

Received on 01 February 2016

Received in revised form on 07 March 2016

Accepted on 11 March 2016

\section{Editor:}

Herminio Ismael de Araújo-Júnior, Universidade do Estado do Rio de Janeiro, Brazil
Citation:

Bergamaschi, S., Duarte, A.C.F., Serrano, J.S., Figueiredo, A.M.B., Vasconcelos, L.C., Oliveira, R.M.A.G., Ade, M.V.B., Pinheiro, A.E.P.P., Martins, M.V.A., 2016. Regional outcrops with didactic interest and sedimentary facies association of the Itararé Group at São Paulo (Brazil). Journal of Sedimentary Environments, 1(1): 153-164.

\begin{abstract}
The main objective of this work is to locate and identify the outcrops considered iconic and valuable as references, not only from the point of view of Cultural or Didactic Tourism, but also in paleoenvironmental reconstruction studies, based on the lithologies that comprise the Itarare Group, in the State of São Paulo, Brazil. This work also intends to relate these sites to outcrops of sedimentary facies, in an area located at south of Itu and Porto Feliz, and north of Sorocaba. The Itararé Group lies within the Paraná Basin (Paleozoic), and is composed by sedimentary sequences associated with the record of the Permo-Carboniferous glaciation event that occurred in the Gondwana supercontinent. This work is based on observations of outcrops in a macro- and mesoscopic scale, considering the characterization of external and internal aspects of the layer,
\end{abstract}

\section{Introduction}

It is well known that throughout the history of the Earth, periods of global warming and cooling occurred, the stratigraphic sequence in the outcrop, and the continuity of the layers within the mapped area. The study area has outcrops where the evidences of glaciomarine deposits predominate. Sedimentary sequences deposited in a subaquatic low-energy environment, as well as episodic deposits, in which relatively more energetic phases alternated with low hydrodynamic conditions are well-developed in the study area. There are also fluvio-deltaic environmental occurrences related to sea level oscillations linked with glacier advances and receding.

Keywords: Geological mapping. Itararé Group. PermoCarboniferous glaciation. Paleoenvironmental reconstruction. Paraná Basin. Sedimentary facies. denominated, respectively, greenhouse and icehouse periods (Assine and Vesely, 2008). During cooling periods, glaciers advanced several times, covering extensive 


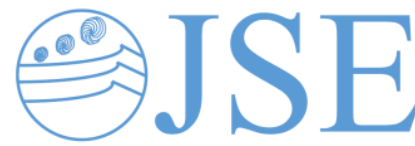

RESEARCH PAPER continental areas, causing glaciation events. During icehouse periods, part of the water available on the surface of the Earth was trapped on the continents as ice or snow, causing a global sea level fall. When planetary temperatures rose, glaciers melted and retreated, causing an increase in the volume of sea water and as a consequence the sea level rise.

This work is based on the study of the lithostratigraphic unit known as Itararé Group, in Paraná Basin, a sedimentary record influenced by the Permo-Carboniferous glaciation that affected the Gondwana supercontinent (Gama Jr. et al., 1992 and references herein).

\subsection{Regional framework}

The Paraná Basin is an intracratonic Paleozoic sedimentary basin (Klemme, 1980) located in the South American continent (Almeida et al., 2000). It covers an area of more than 1.5 million $\mathrm{km}^{2}$, in a region that extends throughout Paraguay, Uruguay, Argentina and Brazil (Milani and Thomaz Filho, 2000). In Brazil, it is located in the SouthCentral part of the country, extending from Mato Grosso state to Rio Grande do Sul state (Fig. 1).

The eastern part of the basin was eroded with the exposition of the crystalline basement due to the rise of the border of the South Atlantic rift (Zanotto, 1993). The basin is limited to the West by the Asunción Arch, created by the lithospheric overburden caused by the Andes belt, and by a sandy depositional limit at N-NE (Milani et al., 1998).

The evolution of Paraná Basin is related to Paleozoic orogeny events during the formation of the Gondwana supercontinent, and later, to its breakup. During the Paleozoic, the basin was located in the western region of South Occidental Gondwana supercontinent, and was affected by several marine transgressions (Zalán et al., 1990).

According to Milani (1997), the Paraná Basin includes 6 Supersequences (Fig. 1): Rio Ivaí (Ordovician-Silurian), Paraná (Devonian), Gondwana I (Carboniferous- EoTriassic), Gondwana II (Meso to Neo-Triassic), Gondwana III (Neo-Jurassic to Eo-Cretaceous), and Bauru (NeoCretaceous). The first three define the transgressiveregressive cycles caused by oscillations of the relative sea level during the Paleozoic, while the others correspond to continental sediment packages with associated igneous rocks. The thickest sedimentary lithostratigraphic units of Paraná Basin, which may have more than 1,000 m thick, is the Itararé Group (França and Potter, 1988).

Itarare Group is a lithostratigraphic unit located in the basal portion of the Gondwana I Supersequence. During the
Neo-Devonian and Eo-Carboniferous, the South Occidental Gondwana was situated at high latitudes, near the South Pole, thus under the effect of a large glaciation (Caputo and Crowell, 1985). Later, Gondwana migrated northward, which was reflected in its climate, which oscillated from glacial to temperate (Caputo and Crowell, 1985). This climactic change gave rise to a glacial melting of the supercontinent and to the Itararé Group proglacial sedimentation (Milani et al., 2007).

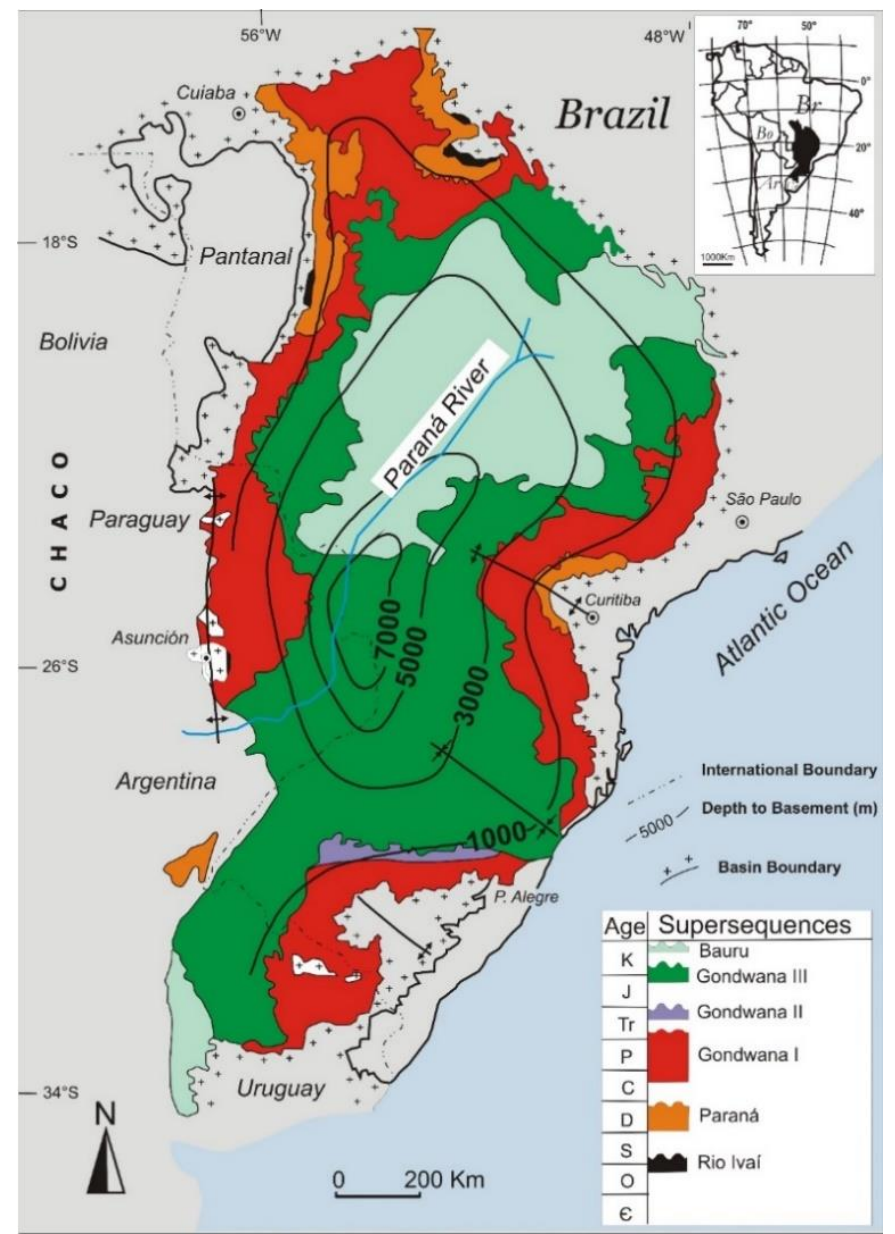

Fig. 1. Geological map of the Paraná Basin and its geographical location. The sedimentary supersequenses that compose this basin and respective ages are mapped (adapted from Milani, 1997).

Thus, Itararé Group is characterized for its very complex facies, constituted by conglomerates, sandstones, diamictites, rythmites and shales, with fallen clasts (França and Potter, 1988). The outcrops of the Itarare Group are composed by sediments deposited mostly in glaciolacustrine (Fig. 2), glacio-marine (Fig. 3), fluvio-glacial and alluvial fan environments (Vesely and Assine, 2004). The facies complexity of Itararé Group increases significantly 
from South to North, that is, from Rio Grande do Sul State to São Paulo State (Vesely and Assine, 2004). In São Paulo State there is no sharp lateral continuity of the Itararé Group lithology as occurs in the southern region. Consequently, the greater complexity hindered the construction of a widely accepted lithostratigraphic model for São Paulo state.

A ice-contact lake

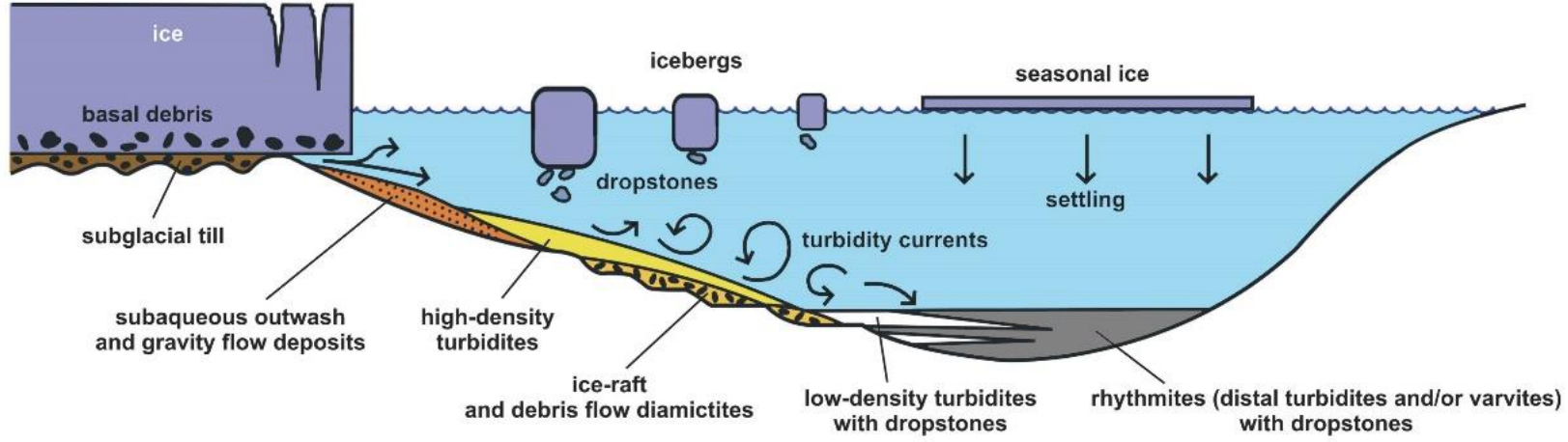

B

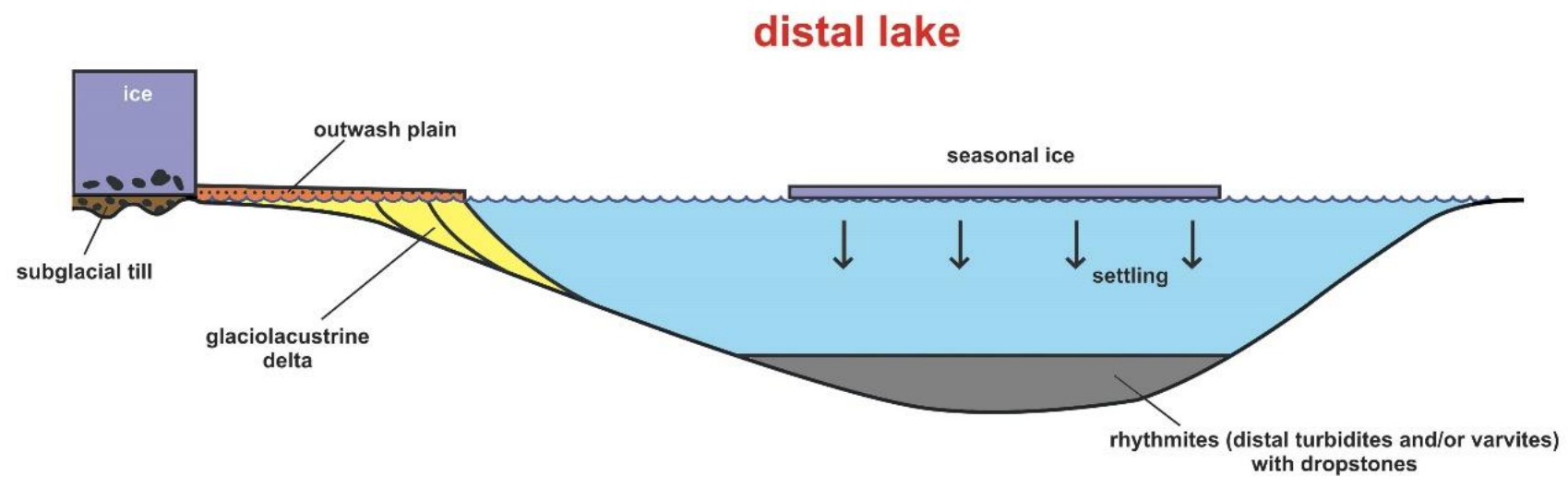

Fig. 2. Diagram representing a glacio lake environment. Adapted from Assine and Vesely (2008).

\subsection{Main aims}

The main objective of this work was to locate and describe outcrops considered of great interest both from the didactic or Cultural Tourism point of view, but also of importance to studies of paleoenvironmental reconstruction of the Permo-Carboniferous glaciation of the Gondwana supercontinent, in São Paulo State (Brazil). It also sought to contextualize these outcrops in a map of the sedimentary facies association of Itararé Group, in an area to the south of Itu, Porto Feliz and north of Sorocaba.

\section{Material and Methods}

Fieldwork was carried out in July of 2015, in the region located at south of Itu, Porto Feliz and at north of Sorocaba, in East-Central São Paulo State (Brazil). It consisted of the study and description of regional sites of outcrops considered didactic, due to having facies typical of Itararé Group. These facies can be found along the study area, with more or less significant occurrences.

In the identification of the facies, the concept suggested by Selley (1970) was adopted. In it, the term facies is employed in the sense of reconnaissance of sedimentary units, characterized and distinguished from adjacent units by basic sedimentary attributes, such as lithology, color, sedimentary structure, layer geometry, paleocurrents, and fossils, among others.

In order to carry out the geological mapping, outcrop sites of Itararé Group were selected, especially in active or abandoned quarries, landscaping areas, in industrial sites, along cuts on dirt roads, highways and railroads, besides drainage fields. Each site was analyzed in different scales: hand sample scale of the rock layer, visualizing its internal and external aspects; stratigraphic sequence of the outcrop 
and of the continuity of the layers in the mapped study area. Each site considered of interest was georeferenced, described and photographed.

The studied points (Tabs. 1 and 2) were georeferenced with a GPS (Garmin, model e'Trex). The utilized datum was Córrego Alegre. The orientation of the identified sedimentary structures was determined with a compass (Clar type, model Gekom-
Breithaupt). Estimated direction is indicated by the symbol S0. Similar facies found elsewhere in the study area were correlated, considering their geographical location and stratigraphy. The facies and facies association data from the two best outcrops, site 3 and 19, were analyzed and interpreted with more detail. The maps were produced with ArcGis software, version 10.0, and the figures with Corel Draw, version 12.

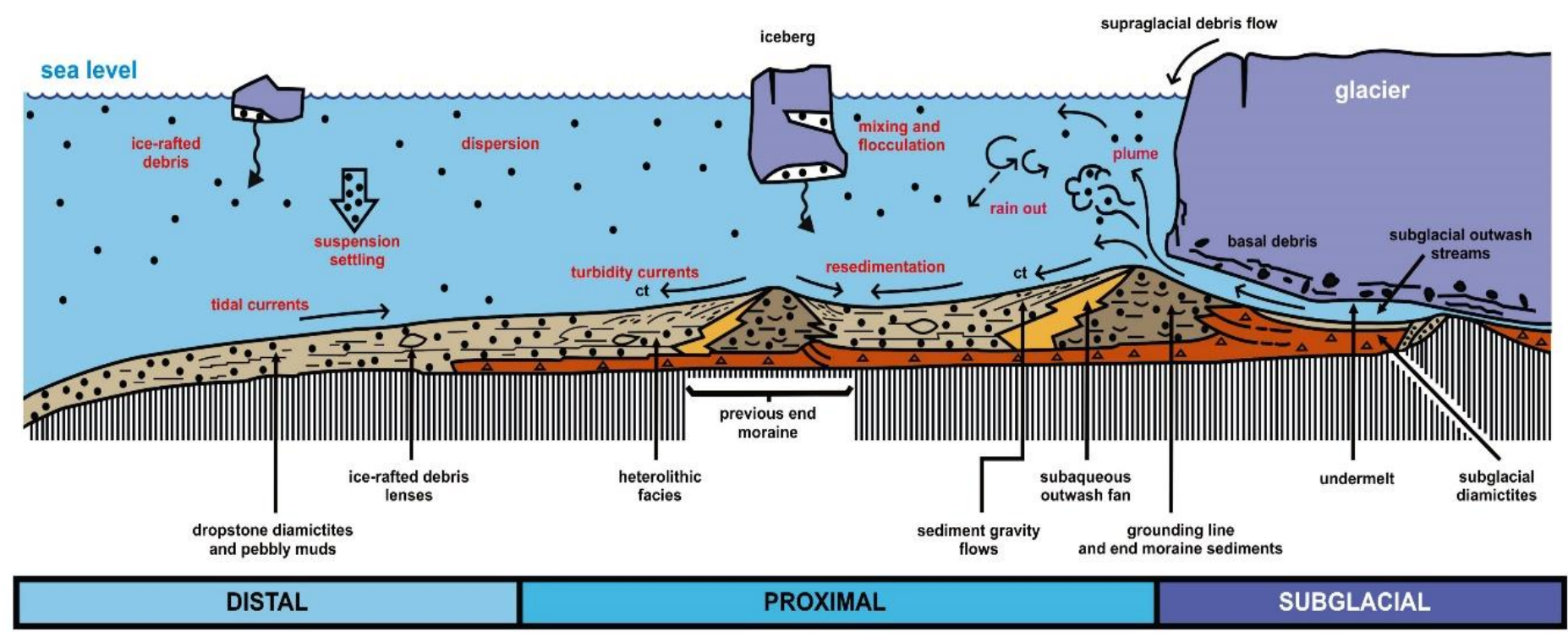

Fig. 3. Schematic diagram representing a glacio-marine environment. Adapted from Assine and Vesely (2008).

Tab. 1. Metric coordinates (UTM coordinates; datum: Córrego Alegre) of the regional outcrops in the region where several facies of the Itararé Group can be observed and studied. The study area is the $23 \mathrm{~K}$ in the American system of UTM coordinates (datum: Córrego Alegre).

\begin{tabular}{|c|c|c|c|c|}
\hline Site & Latitude & Longitude & Elevation (m) & Notes \\
\hline R1 & 241316 & 7431029 & 489 & $\begin{array}{l}\text { Parque das Monções (Monsoons Park), in the } \\
\text { municipality of Porto Feliz (SP) }\end{array}$ \\
\hline $\mathrm{R} 2.1$ & 261653 & 7426852 & 540 & Abandoned quarry, with direction N-S \\
\hline $\mathrm{R} 2.2$ & 261653 & 7426852 & 546 & $\begin{array}{l}\text { Train line cut, S-N oriented, close to the former quarry } \\
\text { outcrop }\end{array}$ \\
\hline R3 & 262176 & 7432814 & 520 & Roadblock outcrop \\
\hline R4 & 261653 & 7428427 & 551 & $\begin{array}{l}\text { Outcrop in roadblock on the Marechal Rondon } \\
\text { Highway }\end{array}$ \\
\hline R5 & 254408 & 7428428 & 550 & $\begin{array}{l}\text { Outcrop in roadblock on Porto Feliz-Boituva } \\
\text { Highway }\end{array}$ \\
\hline R6 & 264315 & 7431357 & 514 & $\begin{array}{l}\text { Outcrop of Parque da Rocha da Moutonnée } \\
\text { (Moutonnée Park) }\end{array}$ \\
\hline
\end{tabular}


Tab. 2. Metric coordinates of the new studied outcrops where several facies of the Itararé Group can be observed and studied. The study area is the $23 \mathrm{~K}$ in the American system of UTM coordinates (datum: Córrego Alegre).

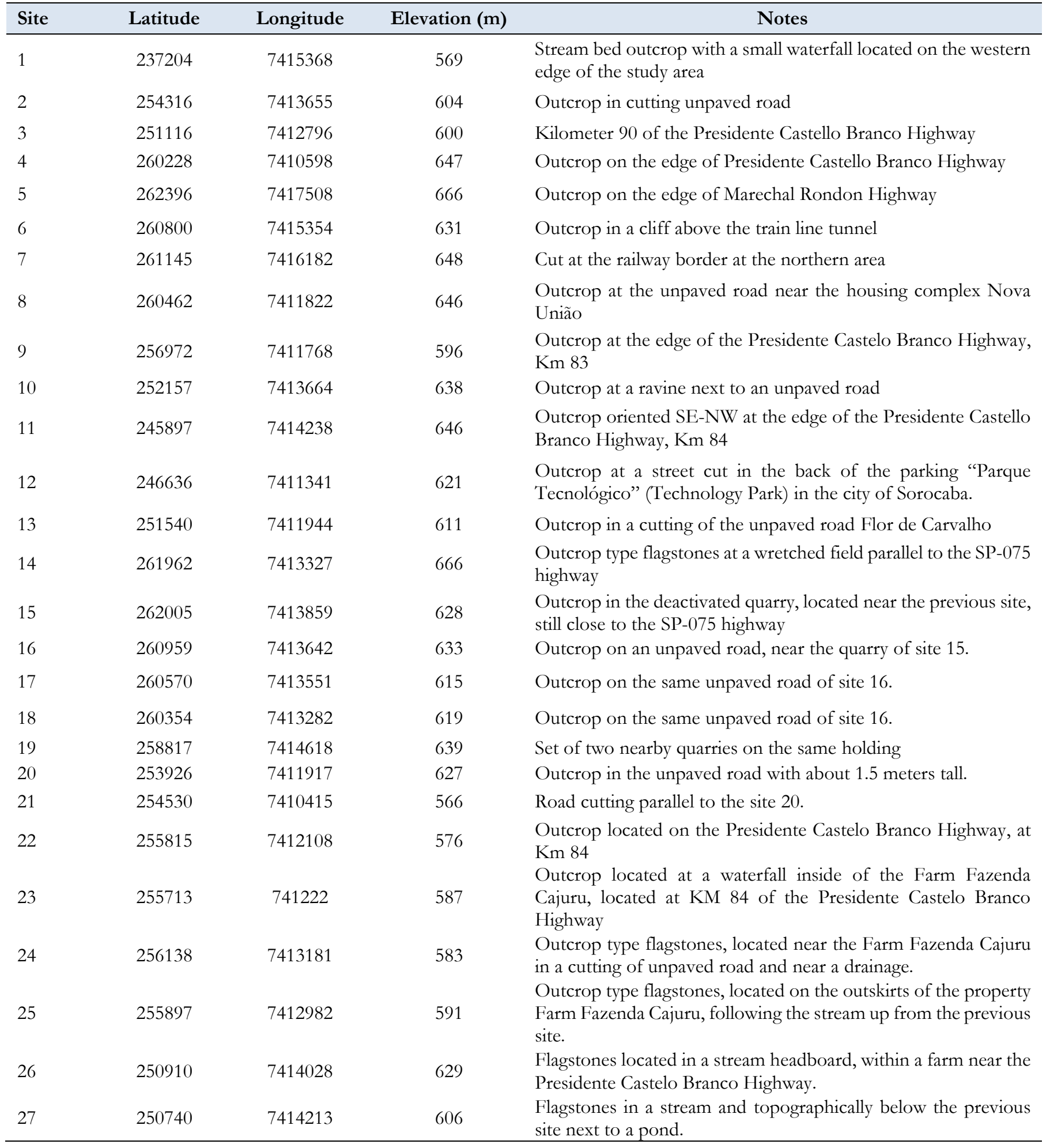




\section{Results and Discussion}

The location of the sites with didactic interest, where various facies of the Itararé Group outcrops can be visited and studied, are listed in Table 1. Their descriptions are presented in Appendix 1. The coordinates of the twentyseven new sites in the study area are listed in Table 2, and their respective descriptions are included in Appendix 2. Eleven sedimentary facies (lithofacies) were identified in the study area, utilizing the concept suggested by Selley (1970) (Table 3). The characterization of those facies is shown in the following topic.

\subsection{Sedimentary facies}

Conglomeratic Sandstone (Gp) - Conglomeratic facies, yellowish beige sandstone package with metric thickness (Fig. 4A). It has a medium to coarse grain size, exhibits tabular stratification, tangential to the base, clay intraclasts and some conglomeratic levels at the base of the channel structures. These conglomeratic levels should be related to several high-energy pulses followed by low hydrodynamic conditions, generating fining upwards stratification. Some clasts of the conglomeratic levels are rounded and others angular, polymictic with varied grain sizes. In some portions of the outcrop, it is possible to see a clayish level, indicating a further reduction in the energy of the flow.

Sandy Diamictite (Dm) - Sandy matrix, yellow diamictite, with metric thickness. Immature, polymictic, fine sand matrix, faceted and angular clasts up to $10 \mathrm{~cm}$. This rock exhibits massive structure, with tabular or sigmoidal geometry (Fig. 4B).

Clayish Diamictite (Df) - Orange diamictite with metric thickness. Contains clayish matrix, with angular, faceted and rounded polymictic clasts. It has a massive internal structure and presents tabular geometry or sigmoidal lobes (Fig. 4C).

Tab. 3. Sedimentary facies and its respective codes identified in 27 locations (points) considered of interest in the study area.

\begin{tabular}{|c|c|c|}
\hline Facies & Codes & Sites \\
\hline $\begin{array}{l}\text { Conglomeratic sandstone and } \\
\text { conglomerate }\end{array}$ & $\mathrm{Gp}$ & 3,27 \\
\hline Sandy diamictite & $\mathrm{Dm}$ & $2,3,20, \mathrm{R} 2.1, \mathrm{R} 3, \mathrm{R} 4$ \\
\hline Clayish diamictite & Df & $3,6,14,20, \mathrm{R} 2.1$ \\
\hline Massive sandstone with matrix & $\mathrm{Smm}$ & $\begin{array}{c}2,3,4,7,8,9,10,11,12,15,16,19,22,23,24 \\
25,26,27\end{array}$ \\
\hline Medium sandstone & Smf & 1,3 \\
\hline Sigmoidal sandstone & Ssp & 4, R1 \\
\hline Fining upwards sandstone & Sh & 3,5 \\
\hline Tabular sandstone with ripples & Str & R1, R2.1, R2.2, R3, R4, R5 \\
\hline Rythmite & $\mathrm{Rh}$ & $10, \mathrm{R} 2.1$ \\
\hline Massive or conchoidal siltstone & $\mathrm{Fm}$ & $\begin{array}{c}1,6,7,9,10,12,13,14,15,16,17,18,19,21,22 \\
24,25,26,27\end{array}$ \\
\hline Shale & $\mathrm{Fl}$ & $1,4,11,12,19,20,21, \mathrm{R} 2.1, \mathrm{R} 2.2, \mathrm{R} 3, \mathrm{R} 4 \mathrm{R} 5$ \\
\hline
\end{tabular}

Massive Sandstone with Matrix (Smm) - Sandy facies with yellowish beige color, mainly composed by fine to medium sand particles, with matrix, coarse quartz grains, and clay intraclasts. This facies has metric thickness, tabular and sigmoidal geometry and exhibits massive structure, slump features and conchoidal fracture (Appendix 2, Fig. A2.3; site 3).
Medium Sandstone (Smf) - Yellowish beige sandstone and red alteration, with metric thickness that thin towards the NW and SE edges (Fig. 4D). In general, the package is massive and exhibit eventual millimetric lamination in the fine sand levels. It is composed mostly by medium sand grain size and well sorted sedimentary particles. 

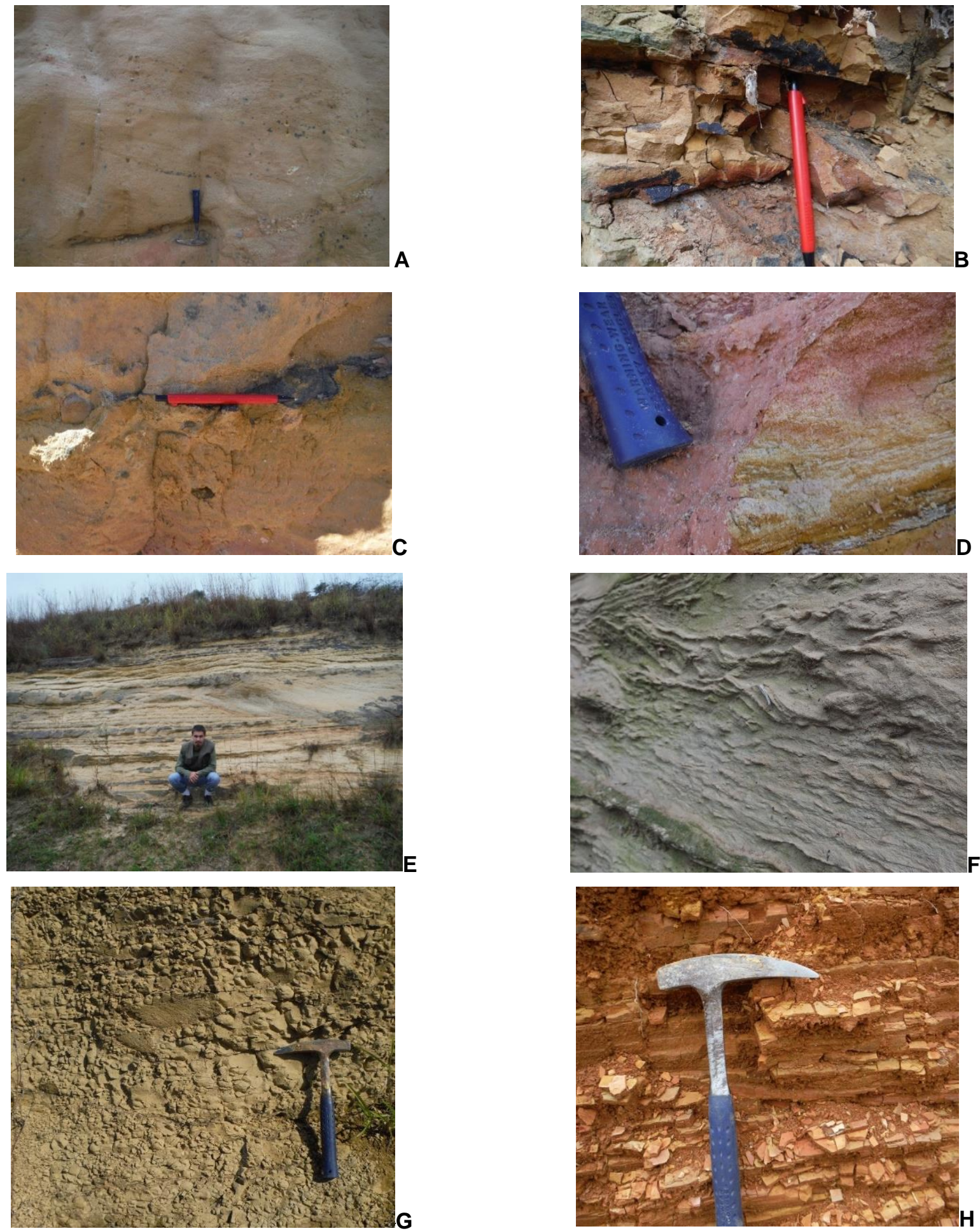

Fig. 4. Sedimentary facies identified in the study area: A. Conglomeratic Sandstone with conclomeratic levels in the base (Facies Gp, site 3); B. Sandy matrix diamictite (Facies Dm, site 20); C. Clayish matrix diamictite (Facies Df, site 3); D. Medium sandstone, massive and with laminated layers (Facies Smf, site 3); E. White sandstone with horizontal, tabular and trough cross stratification, ripples on top, and channel geometry and terminations as onlap, downlap, toplap and truncation of the layers (Facies Sh, site 5); F. Tabular sandstone with current ripples (Facies Str; Site R1); G. Siltstone with conchoidal fracture (Facies Fm, site 1); H. Brownish beige decimetric layers of shale, with lamination and tabular geometry (Facies Fl, site 20). 
This Smf sandstone exhibits fining upwards and contains clay intraclasts, indicating a high-energy flow that could have incorporated pieces of the substrate.

Sigmoidal Sandstone (Ssp) - Fine to medium sandstone, white or yellowish, well selected grain size, generally with sigmoidal external geometry. It exhibits tabular cross stratification, climbing ripples, plane-parallel lamination or massive structure (Appendix 1, Fig. A1.2; site R1).

Fining Upwards Sandstone (Sh) - White sandstone with horizontal, tabular and trough cross stratification, ripples on top, and channel geometry (Fig. 4E). It exhibits fining upwards (normal gradation), varying from very fine to medium sand.

Tabular Sandstone with Ripples (Str) - Decametric tabular strata of fine to medium grain size sandstone, massive, laminated or with unidirectional flow ripples (climbing ripples). Sometimes, form thick sets of tabular strata with large lateral continuity (Fig. 4F).

Rythmite (Rh) - Facies composed of intercalated laminas of siltstone and fine/very fine sandstone. It has lamination and current ripples in the sandy portions (Appendix 2, Fig. A2.18; site 10). It has tabular external geometry, with deformation internal features.

Mudstone (Fm) - Mudstone facies, including claystone and siltstone, light reddish, beige or gray color, massive or with incipient lamination, sometimes presenting conchoidal fracture. It has tabular external geometry, and decametric or metric thickness. Fine sandy lens with current ripples are occasionally present (Fig. 4G).

Shale (F1) - Brownish beige decametric and metric layers of shale and laminated siltstone. The package exhibits lamination and tabular geometry (Fig. 4H).

\subsection{Stratigraphic columns}

\subsubsection{Stratigraphic column of Site 3}

The stratigraphic column (Fig. 5) of site 3 (Figure A2.6) is constituted of the following lithologies from base to top:

- Clayish diamictite (Df), orange to orange-brown diamictite layer approximately $1 \mathrm{~m}$ thick, clayish matrix with polymictic clasts of various grain sizes. Some clasts are rounded and others angular and faceted. The facies has massive structure with tabular geometry. A dark layer of manganese oxide marks the contact with the conglomeratic sandstone at the top of the layer.

- Conglomeratic sandstone with tangential crossstratification (Gp; Fig. 5-6) followed by conglomeratic sandstone with tabular crossstratification (Gp; Fig. 5-7) which present some clay lens (Figs. 5-10, 11). These facies are separated by erosive base (Fig. 5-12). These layers have about $4 \mathrm{~m}$ thickness.

- Clayish diamictite (Df; Fig. 5-4) followed by sandy diamictite (Dm; Fig. 5-5), which displays flame structures (Fig. 5-9). On this facies is deposited a medium sandstone (Smf; Fig. 5-3) with load cast structures (Fig. 5-8). There are intercalations of sandy diamictite with $3 \mathrm{~m}$ thickness.

- Massive sandstone with matrix and granules (Smm; Fig. 5-2). This layer is about $2.5 \mathrm{~m}$ thickness.

- Sandy diamictite (Dm; Fig. 5-5) followed by clayish diamictite (Df; Fig. 5-4). These layers have about 2.0 $\mathrm{m}$ thickness.

- Massive sandstone with matrix (Smm; Fig. 5-1). This layer has about $2.0 \mathrm{~m}$ thickness.

\subsubsection{Stratigraphic column of Site 19}

The stratigraphic column (Fig. 6) of site 19 (Appendix 2, Fig. A2.28) is constituted by the following lithologies from base to top:

Massive or Conchoidal siltstone (Fm) - Grey siltstone package $4 \mathrm{~m}$ thick, with weak lamination and tabular geometry. The package exhibits a conchoidal fracture pattern, besides vertical plane fractures with smooth surface and millimetric displacement. The siltstone is interbedded with the claystone package above, and has desiccation cracks.

Shale (Fl) - Brownish beige decimetric layers of shale. The package is $4 \mathrm{~m}$ thick. The shale has clay grain size, is laminated, and has tabular geometry. The shale layers contain manganese oxide.

Claystone (Fm) - Yellowish beige centimetric claystone layers alternating with decimetric shale layers. The claystone layers increases in thickness towards the top. The package is $4 \mathrm{~m}$ thick. The claystone is massive and has tabular geometry. The shale layers contain manganese oxide.

Massive sandstone with matrix (Smm) - The yellowish beige sandstone is $1.5 \mathrm{~m}$ thick. It has fine to medium grain size and exhibits fining upwards. The rock is well sorted, immature, and contains clay intraclasts, indicating that it is associated with a high-energy flow that 


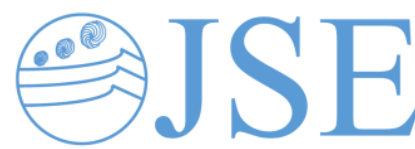

RESEARCH PAPER

incorporated pieces of the claystone below. The package is massive and its layers thin towards the edges, NW and SE.

Claystone (Fm) - Yellowish beige claystone package 4.5 $\mathrm{m}$ thick. The claystone is massive and has a tabular geometry.

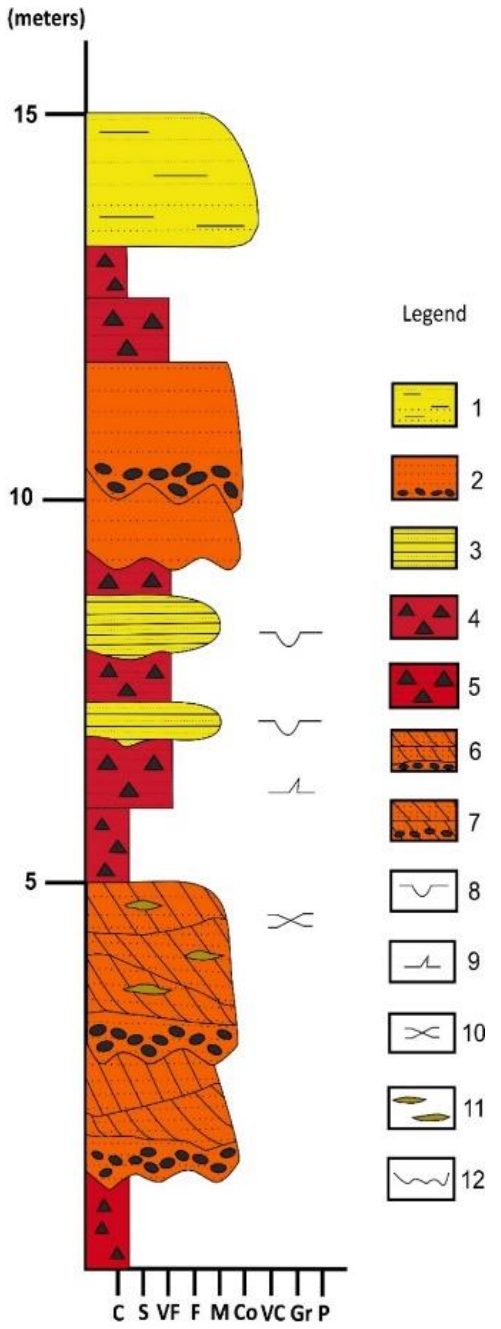

Fig. 5. Stratigraphic column of outcrop 3. 1- Smm. Massive sandstone with matrix. 2- Smm. Massive sandstone with matrix and granules. 3- Smf. Medium sandstone. 4- Df. Clayish diamictite. 5- Dm. Sandy diamictite. 6- Gp. Conglomeratic sandstone with tangential cross-stratification. 7- Gp. Conglomeratic sandstone with tabular cross-stratification. 8- Load casts. 9- Flame structure. 10, 11- Clay lens. 12- Erosive base. Legend of granulometric scale: C - clay; S - silt; VF - very fine-grained sand; F - fine-grained sand; M - medium-grained sand; Co - coarse-grained sand; VC - very coarse-grained sand; Gr - granule and; P - pebble.

Some of the sedimentary sequences found in the study area indicate, indeed, the occurrence of fluvio-deltaic deposits; such examples are the conglomerate deposits and coarse sands cutting each other and eroding older deposits over which they were deposited. Other evidence of the fluvio-deltaic system is the channel geometry and its tabular internal structures, characteristic of this type of environment.

\subsection{Facies association of Site 3}

The conglomeratic sandstone package was observed only at sites 3 and 27. Its distinctive characteristic is the presence of the channel geometry and tabular cross stratification, besides the greater concentration of clasts. The diamictite packages were observed at sites 2, 3, 6, 14, 20, R2.1, R3 and $\mathrm{R} 4$, in the central and NE zones of the study area. The existence of medium sandstone only was observed in sites 3 and 1. However, there are sandstones alternating with diamictites in the other sites.

The occurrence of the massive sandstone with matrix, in site 3 and in 15 other sites of the study area, NW-SE axis and extreme and (Tab. 3), is an evidence of the occurrence of an episodic flow. It would have been dominated by gravitational flow mechanisms, and would have been responsible for the transport of sediments of different grain size and origin.

\subsection{Facies association of Site 19}

At site 19, there are two siltstone packages at the base, whose facies are observable at 11 other sites, concentrated in the central and NE portions of the study area (Tab. 3). On the other hand, the claystone is characteristic of distal portions of the study area, and is found along a SW-NE axis, from the center to the East. The alternation of red claystone and shale is interrupted by an immature, massive sandstone package, common in the study area. The continuation of the outcrop is a sequence of claystones that are likely associated with hydrodynamic conditions dominated by calm currents. These packages reach metric thicknesses and occur repeatedly in the sedimentary column, as seen at site 3 .

This allows deducing that these packages represent a period where the hydrodynamic conditions were relatively calmer in relation to the regional environment in which they lie.

\subsection{General discussion}

In the study area, the facies associations found are constituted mainly by (Fig. 7): 1) polymictic diamictite (with faceted clasts, clay intraclasts and sigmoidal geometry) associated with medium to conglomeratic sandstone, with channel geometry; 2) tabular geometry siltstone with fine to 


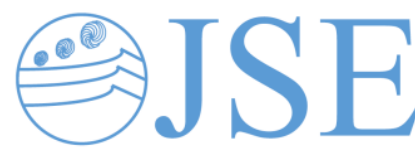

RESEARCH PAPER

very fine deformed sandstone lenses and; 3) tabular siltstone with massive and deformed claystone.

The occurrence of the diamictite facies may be associated with a gravitational debris flow related to a melting phase of the glacier.

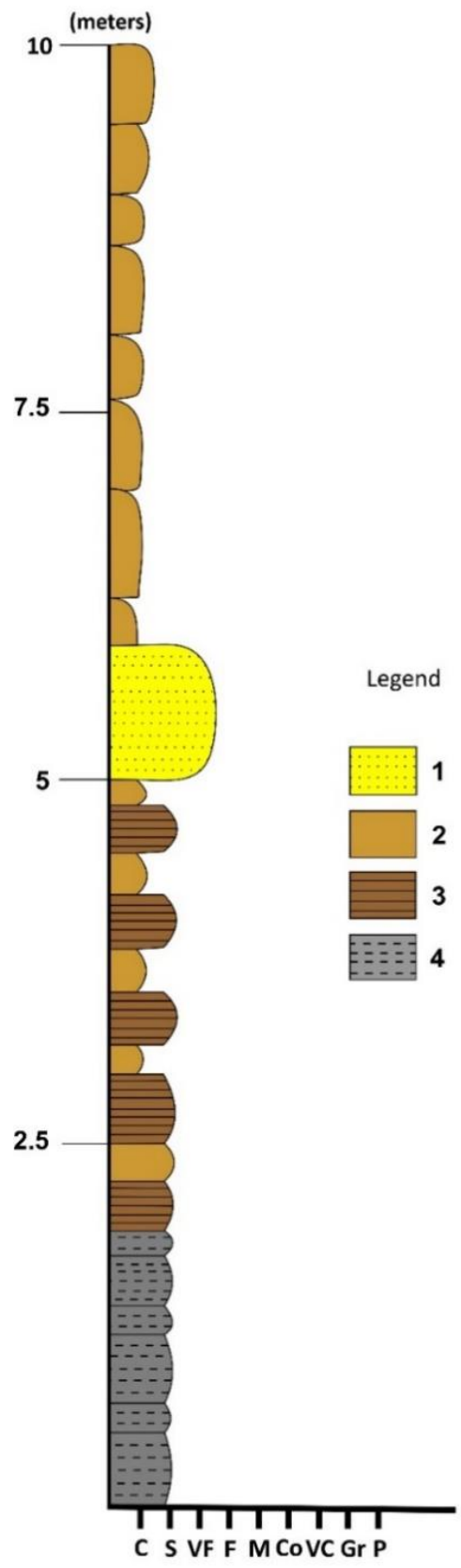

Fig. 6. Stratigraphic column of the outcrop 19. 1- Smm. Massive Sandstone with Matrix. 2- Fm. Claystone. 3- Fl. Argillaceous shale. 4- Fm. Conchoidal Siltstone. Legend of granulometric scale: $\mathrm{C}=$ clay, $\mathrm{S}=$ silt, $\mathrm{VF}=$ very fine-grained sand, $\mathrm{F}=$ fine-grained sand, $\mathrm{M}=$ medium-grained sand, $\mathrm{Co}=$ coarse-grained sand, $\mathrm{VC}=$ very coarse-grained sand, $\mathrm{Gr}=$ granule and $\mathrm{P}=$ pebble.
The conglomeratic medium sandstone package was seen only at sites 3 and 27 . Their distinctive characteristic is the presence of channel geometry and tabular cross stratification, besides having greater concentration of clasts. According to the faciological description of Vesely and Assine (2004), this facies is likely due to a proximal flow or a fluvio-deltaic system, whose origin is associated with detritus flows from melting glaciers.

The stratigraphic column of site 3 registers the existence of several diamictite deposition cycles, over which sandstone was deposited, which suggests the occurrence of episodic flows in the basin. These cycles of the stratigraphic passage from diamictite to sandstone and vice-versa may be also associated with a sudden change in the energy flow in the basin. They also reveal alterations in the flow characteristics and transport processes that affect the deposition of these sedimentary layers. This aspect becomes clearer with the difference in grain size of the matrix of the two diamictites, one clayish (found at sites 3, 6, 14 and 20) and the other sandy (found at sites 2, 3 and 20), suggesting a change in the flows energy.

The chaotic arrangement of the medium sandstone package at site 3, compared to the other outcrops of this facies, reveals another aspect of the sedimentation in the basin. It may be associated with a moment when sandstones are deposited, while the diamictites were not yet consolidated. This could have been the cause of perturbations in the plastic state of these sedimentary packages generating flame and load cast structures.

According to the Vesely and Assine (2004) model, the occurrence of fine, laminated deposits associated with sandstones and conglomerates, channel geometry, cross stratification, fining upwards, and deformation features, support the hypothesis that these deposits are fluvio-deltaic. They may have been originated by slides in subaquatic fans. The slides may have caused material resuspention, which would have been deposited later. The covering of the outwash sandstones and conglomerates by finer facies of the association, well represented in stratigraphic sequence 19, indicates a retraction of the glacier margin.

According to Rust and Romanelli (1975), shales associated with siltstone represent the facies with least glacial influence, formed by the decantation of clays in suspension, and may have been the product of sedimentation in subaquatic proglacial environment. Thus, part of the flow of the steep face of the sliding subaquatic fan behaves as a plume that maintains fine sediments in suspension. The decantation of this plume and occasional fallen clasts from icebergs (debris rain) may also have originated the massive diamictites in steep face of fan. 


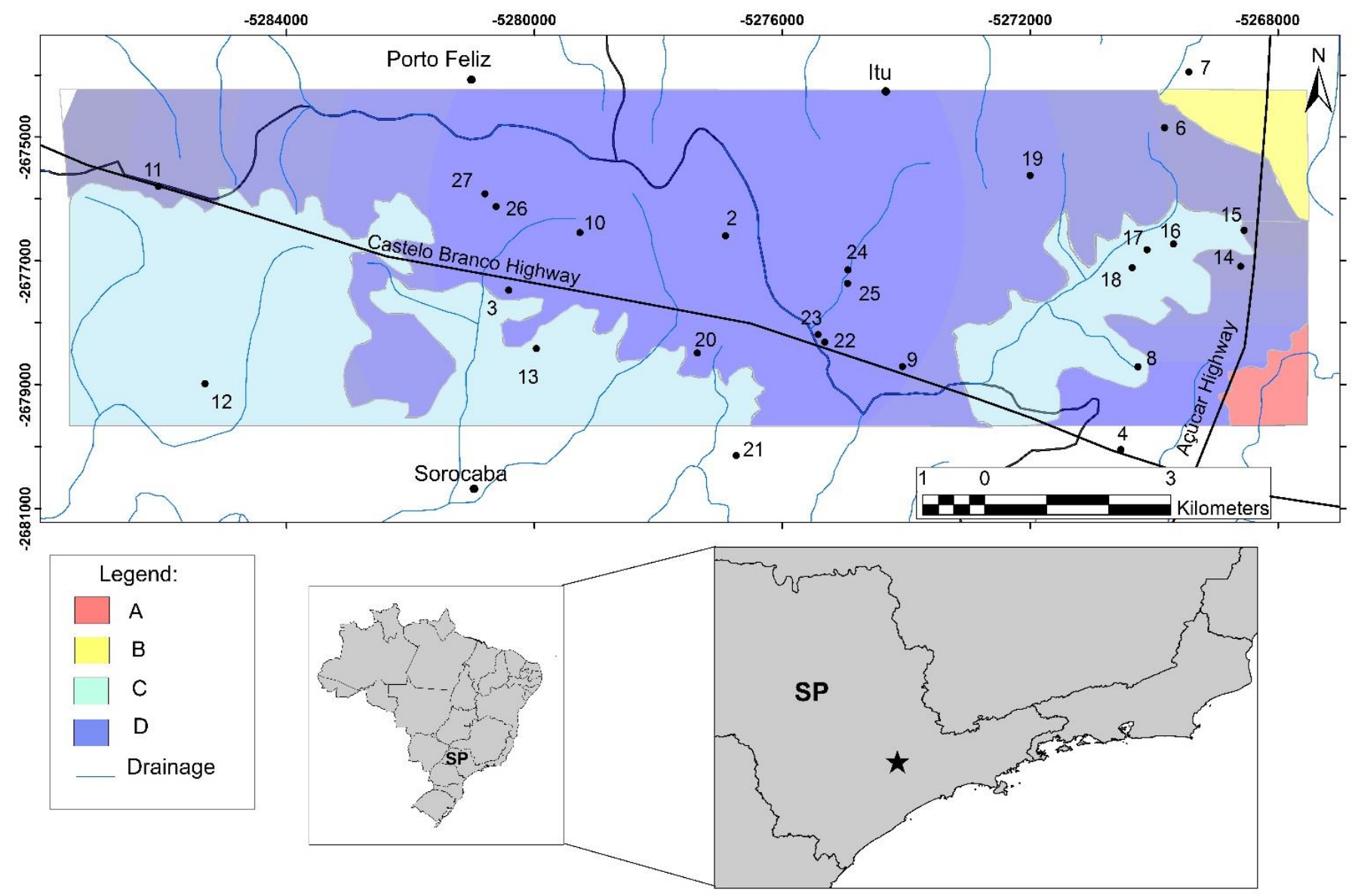

Fig. 7. Map of the studied sites (above) in the study area of São Paulo State (Brazil). The main cities, highways and streams are presented in this map. Facies associations are shaded in the map (above). Legend: A - basement; B - fluviodeltaic facies association; C - glaciomarine facies association related to low hydrodynamic conditions; D - glaciomarine facies association with episodic deposits.

Considering the tabular, massive and homogeneous character of the siltstone packages of site 19, it can be deduced that this facies could be associated with low glaciomarine energy.

The deposition of the red shales is interrupted by common immature massive sandstone package throughout of the area. These sandy deposits are interpreted as episodic events with more energy. These deposits should be related to slumping and/or the presence of hyperpycnal flow which were able to carry sandy particles to distal portions of the basin, in the defrosting periods.

The occurrence of frequent sandstones deposits with ripples; diamictites with sigmoidal lobe geometry; deformed rhythmites; massive, fine to coarse sandstones with channel and tabular cross structures; as well as massive fluidized sandstones and diamictites, support the hypothesis that the record in this region of the Paraná Basin is constituted by episodic deposits. These deposits cause perturbations in the normal basin sedimentation, and are generated by highenergy flows, mass slides/movements, and turbiditic flows.

The intercalation of shale and siltstone and the absence of coarser deltaic facies (sandstones and conglomerates), is an evidence of deposits associated with reduced hydrodynamic conditions, in prodeltaic ou interfan domains.

In general, the most typical facies associations of the study area may be associated with glacio-marine and fluviodeltaic environments. The fining-upwards tendency observed in some outcrops may be associated with 
transgressive cycles due to a receding glacier, caused by climactic warming and melting and the consequent rise in relative sea level.

\section{Conclusion}

The faciological complexity of the sedimentary record found in the studied region is great with features typical of glacial environments, such as poor sorting and immaturity, faceted clasts, glacial dropstones, lithic fragments. These lithological features and the facies associations found allows us to deduce that in the study area a glacio-marine environment prevailed. However, in the NE region it is possible to identify a fluvio-deltaic facies association.

The glacio-marine environment is overlain by layers of horizontal fines, deposited in the basin by decantation, by sporadic events such as mass flows. Based on the analysis of the resulting geological map, it is possible to deduce that there was an episodic entry of sediments associated with high energy. These sediments were linked with NE-SW direction flows, deposited over pelitic facies related to low energy conditions. These conditions prevailed in all the central part of the study area. The episodic deposits must have been originated during climatic warming periods, in which glaciers retreated and melted, giving rise to transgressive events.

Acknowledgments

The authors would like to thank the reviewers of JSE, the State University of Rio de Janeiro - UERJ for funding and support given for the fieldwork and to Cleveland M. Jones for the manuscript proofreading.

Appendix 1 and Appendix 2 are attached as supplementary material 1 (SM1) and supplementary material 2 (SM 2) in http://www.epublicacoes.uerj.br/index.php/jse/article/view/21964

\section{References}

Almeida, F.F.M., Neves, B.B., Carneiro, C.D.R., 2000. The origin and evolution of the South American Platform. Earth Science Reviews 50, 77-111.

Assine, M.L., Vesely, F.F., 2008. Ambientes Glaciais. In: Pedreira, A.J., Aragão, M.A.N.F., Magalhães, A.J. (eds), Ambientes de Sedimentação Siliciclástica do Brasil, São Paulo, BECA, pp. 24-51.
Boulton, G.S., 1979. Processes of glacial erosion on different substrata. Journal of Glaciology 22, 15-38.

Caputo, M.V., Crowell, J.C., 1985. Migration of glacial centers across Gondwana during Paleozoic Era. Geological Society of America Bulletin 96, 1020-1036.

França, A.B., Potter, P.E., 1988. Estratigrafia, ambiente deposicional e análise de reservatório do Grupo Itararé (Permocarbonífero), Bacia do Paraná (Parte 1). Boletim de Geociências da Petrobras, Rio de Janeiro 2 (2/4), 147-191.

Gama Jr., E.G., Perinotto, J.A.J., Ribeiro, H.J.P.S., Padula, E.K., 1992. Contribuição ao estudo da ressedimentação no Subgrupo Itararé: tratos de fácies e hidrodinâmica deposicional. Revista Brasileira de Geociências 22, 228-236.

Klemme, H.D., 1980. Petroleum basins - Classifications and characteristics. Journal of Petroleum Geology 3, 187-207.

Milani, E.J., Melo, J.H.G., Souza, P.A., Fernandes, L.A., França, A.B., 2007. Bacia do Paraná. Boletim de Geociências da Petrobras, Rio de Janeiro, 15(2), 265-287.

Milani, E.J., Thomaz Filho, A., 2000. Sedimentary basins of South America. In: Cordani, U.G., Milani, E. J., Thomaz Filho, A., Campos, D. A. (ed.) Tectonic Evolution of South America. 31st IGC, Rio de Janeiro, Brazil, Special Publication, pp. 389-449.

Milani, E. J., Faccini, U. F., Scherer, C. M. S., Araújo, L. M., Cupertino, J. A. 1998. Sequences and stratigraphic hierarchy of the Paraná Basin (Ordovician to Cretaceous), Southern Brazil. Boletim IG-USP, São Paulo, Série Científica, 29, 125-173.

Milani, E.J. 1997. Evolução tectono-estratigráfica da Bacia do Paraná e seu relacionamento com a geodinâmica fanerozóica do Gondwana sul-ocidental. PhD thesis, Universidade Federal do Rio Grande do Sul, Porto Alegre, 2 vols.

Rust, B.R.; Romanelli, R., 1975. Late Quaternary subaqueous outwash deposits near Ottawa, Canada. In: Jopling, A.V., McDonald, B.C. (ed.), Glaciofluvial and Glaciolacustrine Sedimentation. Tulsa. Society of Economic Paleontologists. Special Publication 23, 177-192.

Selley, R.C. 1970. Ancient Sedimentary Environments, London, Chapman and Hall, 237 pp.

Vesely, F.F., Assine M.L., 2004. Sequências de tratos de sistemas deposicionais do Grupo Itararé, Norte do Estado do Paraná. Revista Brasileira de Geociências 34(2), 219-230.

Zalán, P.V., Wolff, S., Astolfi, M.A.M., Vieira, I.S., Conceição, , J.C.J., Appi, V.T., Santos Neto, E.V., Cerqueira J.R., Marques, A., 1990. The Paraná Basin, Brazil. In: Leighton, M.W., Kolata, D.R., Oltz, D.F., Eidel, J.J. (eds.), Interior cratonic basins, American Association of Petroleum Geologists, Tulsa, Memoir 51, pp. 681-708.

Zanotto, O. A., 1993. Erosão pós-Cretáceo na Bacia do Paraná, com base em dados de reflectância da vitrinita. In: Resumos do Simpósio Sul-Brasileiro de Geologia 5, Curitiba, Sociedade Brasileira de Geologia, p. 58. 